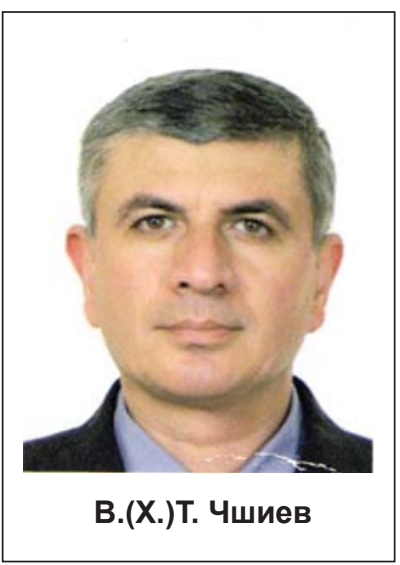

Адайдонский некрополь эпохи поздней бронзы - раннего железа расположен в Зарамагской межгорной котловине, в Алагирском районе Республики Северная Осетия-Алания, на высоте 1600 м н. у. м. [1].

Среди раннего пласта материалов Адайдонского могильника эпохи поздней бронзы - раннего железа, относящихся к кобанской археологической культуре Кавказа, присутствует ряд предметов вооружения со следами преднамеренного повреждения. Это копья, дротики, кинжалы, ножи. Предметы происходят из крупных коллективных гробниц подпрямоугольной формы, сложенных из валунов и сланцевых плит. Сопутствующий рассматриваемым предметам инвентарь представляет ряд артефактов, типичных для раннекобанского периода (период Кобан 1 А по периодизации В.И. Козенковой) и датирующихся в рамках начала XIV - первой половины XII вв. до н. э. [1, с. 91]. Это такие артефакты, как бронзовые булавки с дисковидным навершием, привески в виде головок барана с закрученными рогами раннего типа, топоры-секиры типа Фаскау 7 и Фаскау 8 (по классификации С.Н. Кореневского), бронзовые клювовидные секирыалебарды (тип Фаскау 6) и др.

В контексте рассматриваемой нами тематики правомерен вопрос о времени и природе происхождения повреждений, полученных предметами погребального инвентаря, так как они могут иметь естественное происхождение. К примеру, в результате смещения и давления на инвентарь покровных плит и валунов из стенок гробниц, составляющих конструкцию погребального сооружения, многовекового балласта из дресвы черного сланца и делювия и т. д. Надо отметить, что при первоначальном ознакомлении с рассматриваемым пластом артефактов во время раскопок могильника, природа этих повреждений именно такой мне и представлялась. Однако повторное, более внимательное рассмотрение предметов показало, что характер имеющихся повреждений исключает подобное предположение. Повреждения, имеющиеся
УДК 902.94

DOI 10.23671/NNC.2019.2.31370

\begin{abstract}
Аннотация. В статье рассматриваются некоторые особенности обряда погребения археологических комплексов Адайдонского некрополя эпохи поздней бронзы Кавказа. Ключевые слова: кобанская культура Кавказа, особенности погребального обряда древнего населения Кавказа.
\end{abstract}

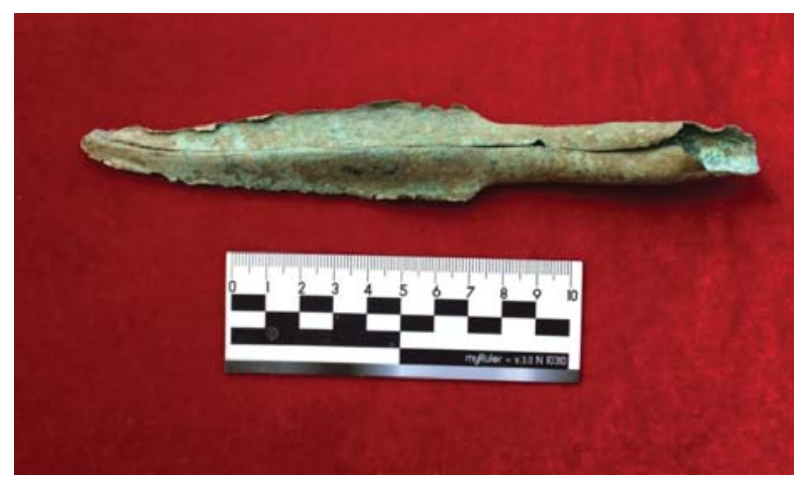

Иллюстрация 1

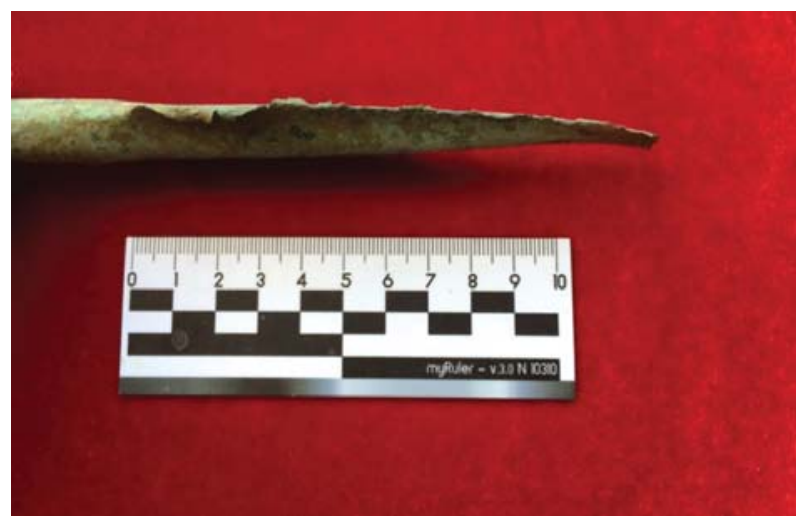

Иллюстрация 2

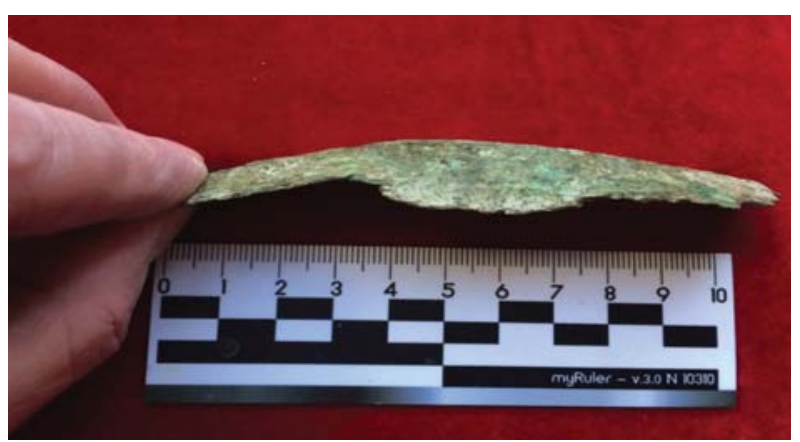

Иллюстрация 3

* Чшиев Владимир Таймуразович - к. и. н. , старший научный сотрудник ГБУ «Институт истории и археологии РСО-А (hacht@mail.ru). 


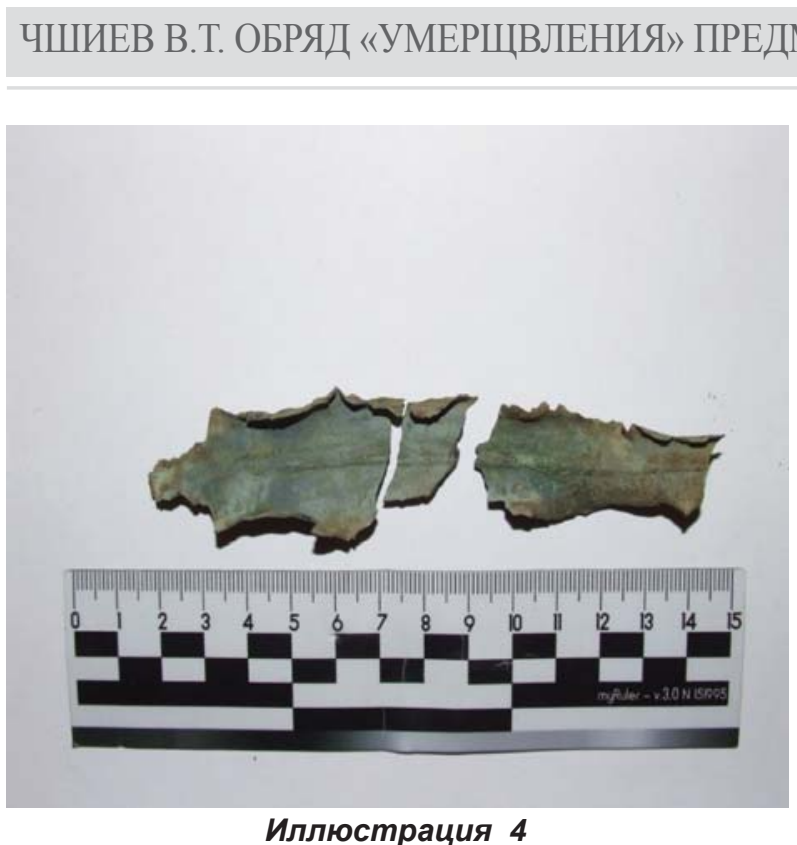

на рассматриваемой нами категории предметов погребального инвентаря, нанесены вследствие неоднократных целенаправленных рубленых ударов по лезвию клинков ножей и кинжалов, наконечников копий, дротиков острым, твердым предметом (по нашему мнению - топором, как его обушной частью, так и рубящей); завальцовкой, сворачиванием, закручиванием, затуплением острой кромки лезвия наконечников копий, дротиков, клинков кинжалов, ножей. Ряд предметов - клинки кинжалов, наконечники копий - сильно согнуты по корпусу и имеют повреждения на кончиках в результате многократных ударов самим оружием по твердому предмету. Подобная амортизация названных предметов невозможна в результате боевых столкновений. Она может быть следствием только целенаправленного повреждения предметов вооружения (к слову, сделанных из довольно крепкого бронзового сплава), в результате прямых ударов острием по камню или металлу.

Рассмотрим подробнее сами предметы и характер нанесенных им повреждений. Из гробницы № 1 происходит наконечник небольшого бронзового копья с раскрытой втулкой и пером листовидной формы (илл. 1-2). Наконечник немного согнут ближе к острию. Лезвие пера завальцовано, вследствие поперечных ударов твердым предметом. В гробнице № 1 был найден фрагментированный бронзовый нож с завальцованной, согнутой в результате ударов тупым предметом типа молота или обуха топора режущей кромки клинка (илл. 3). Аналогичные повреждения имеются на крупном бронзовом ноже или кинжале из гробницы № 76 (илл. 4). На небольшом наконечнике копья имеются рубленые поперечные следы, оставленные острым твердым предметом, как отмечалось выше, вероятно топором (илл. 5.)

Внимательное рассмотрение вышеприведенных предметов не оставляет сомнений в том, что мы имеем дело с намеренным повреждением погребального инвентаря перед помещением в гробницы. Отметим, что подобному воздействию подвергаются наиболее употребительный в бою и бытовом употреблении инвентарь, предметы вооружения и ножи, которые можно назвать «острыми предметами».

Комплексы Адайдонского могильника с намеренно «умерщвленными» предметами, исходя из сопутствующего погребального инвентаря и датировок самих этих предметов, хронологически относятся ко времени XIV-XIII вв. до н. э.

Заслуживает внимания и тот фракт, что украшения и парадные предметы погребального инвентаря, булавки, заколки, бляхи, престижные парадные топоры, секиры, часто изготовленные из слабого металла, вотивные предметы, не подвергались намеренному повреждению перед захоронением.

Известные нам случаи намеренного повреждения предметов перед погребением достаточно далеки и географрически и хронологически от нашего памятника $[3 ; 4 ; 5 ; 6 ; 7 ; 8$. Filip J. Keltove ve Stredni Evrope. - Praha, 1956]

Таким образом, в рассматриваемом нами случае мы имеем пока первый известный нам случай обряда «умерщвления предметов» перед захоронением в памятниках кобанской археологической культуры Центрального Кавказа в эпоху поздней бронзы.

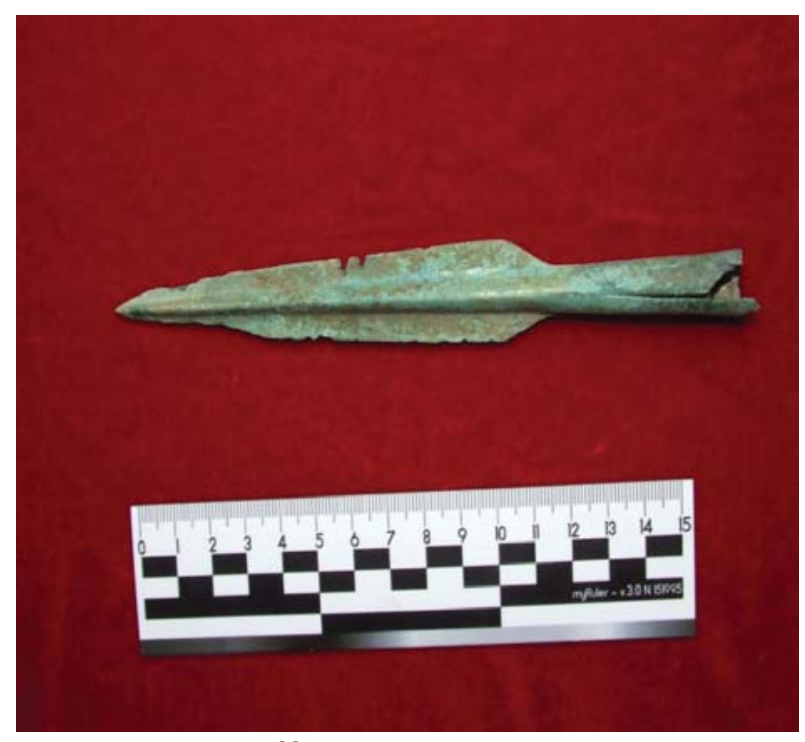

Иллюстрация 5 


\title{
ЛИТЕРАТУРА
}

1. Чшиев Х.T. Раскопки Адайдонского могильника кобан ской культуры в 2006-2007 г2.: Предварительные итоги исследования // Отражение цивилизационных процессов в археологических культурах Северного Кавказа и сопредельных территорий. (Юбилейные XXV «Крупновские чтения» по археологии Северного Кавказа). Тезисы докладов / Oтв. ред. А.А. Туаллагов. - Владикавказ: Издательство СОИГСИ им. В.И. Абаева, 2008. С. 376-380.

2. Козенкова В.И. Культурно-исторические процессы на Северном Кавказе в эпоху поздней бронзы и в раннем железном веке (Узловые проблемы происхождения и развития кобанской культуры). - М.: ИА РАН, 1996. 162 с.

3. Крупнов Е.И. Новый памятник древних культур Даге- стана // МИА. № 23. - М., 1951.

4. Смирнов К.Ф. Археологические исследования в районе с. Тарки // МИА. № 23. - М., 1951.

5. Абрамова М.П. Буйнакский курган // Древние и средневековые археологические памятники Дагестана. - Махачкала, 1980.

6. Бакушев М.А. Обряд порчи инвентаря в памятниках Дагестана албано-сарматского времени // Вестник Института ИАЭ. № 3. - Махачкала, 2005.

7. Бейсенов А.З., Джумабекова Г.С. О древнем ритуале порчи предметов, используемых в обряде погребения кочевников // Поволжская археология. № 2. - Казань, 2017.

8. Filip J. Keltove ve Stredni Evrope. - Praha, 1956.

\section{THE RITE OF BURIAL ITEMS «KILLING»IN THE MATERIALS OF ADAIDON NECROPOLIS}

V. T. Chshiyev

Ph. D., Senior Researcher of the State Institution "History and Archeology Institute of the Republic of North Ossetia-Alania" (hacht@mail.ru)

\begin{abstract}
The article considers certain peculiarities of the burial rite in the archaeological sites of Adaidon necropolis that belongs to the Late Bronze Age of the Caucasus.

Keywords: Koban culture of the Caucasus, the peculiarities of the funeral rite of the ancient population of the Caucasus.
\end{abstract}

\section{REFERENCES}

1. Chshiev H.T. Raskopki Adajdonskogo mogil'nika kobanskoj kul'tury v 2006-2007 gg.: Predvaritel'nye itogi issledovaniya // Otrazhenie civilizacionnyh processov v arheologicheskih kul'turah Severnogo Kavkaza i sopredel'nyh territorij. (Yubilejnye XXV «Krupnovskie chteniya» po arheologii Severnogo Kavkaza). Tezisy dokladov / Otv. red. A.A. Tuallagov. - Vladikavkaz: Izdatel'stvo SOIGSI im. V.I. Abaeva, 2008. S. 376-380.

2. Kozenkova V.I. Kul'turno-istoricheskie processy na Severnom Kavkaze $v$ epohu pozdnej bronzy $i$ v rannem zheleznom veke (Uzlovye problemy proiskhozhdeniya i razvitiya kobanskoj kul'tury). - M. :IA RAN, 1996. $162 \mathrm{~s}$

3. Krupnov E.I. Novyj pamyatnik drevnih kul'tur Dagestana // MIA. № 23. - M., 1951.

4. Smirnov K. F. Arheologicheskie issledovaniya v rajone s. Tarki // MIA. № 23. - M., 1951

5. Abramova M.P. Bujnakskij kurgan // Drevnie i srednevekovye arheologicheskie pamyatniki Dagestana. - Mahachkala, 1980.

6. Bakushev M.A. Obryad porchi inventarya v pamyatnikah Dagestana albano-sarmatskogo vremeni // Vestnik Instituta IAE. № 3. - Mahachkala, 2005.

7. Bejsenov A. Z., Dzhumabekova G. S. O drevnem rituale porchi predmetov ispol'zuemyh $v$ obryade pogrebeniya kochevnikov // Povolzhskaya arheologiya. № 2. - Kazan', 2017.

8. Filip J. Keltove ve Stredni Evrope. - Praha, 1956.

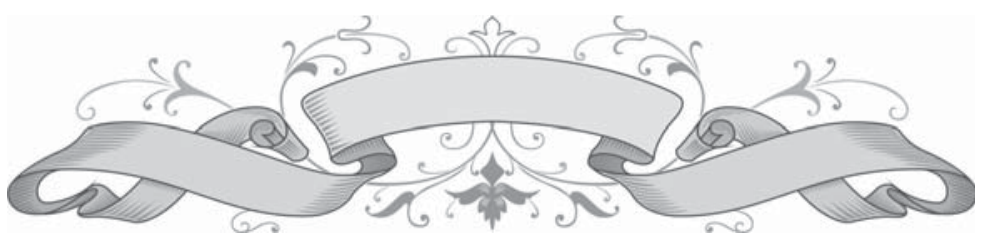

